\title{
Pogostemon guamensis Lorence \& W.L.Wagner (Lamiaceae), a new species from Guam, Mariana Islands
}

\author{
David H. Lorence', Warren L. Wagner², Kenneth R. Wood', Gabriel Johnson² \\ I National Tropical Botanical Garden, 3530 Papalina Road, Kalāheo, HI 96741, USA 2 Department of \\ Botany, Smithsonian Institution, PO Box 37012, Washington, DC 20013-7012, USA \\ Corresponding author: David H. Lorence (lorence@ntbg.org)
}

Academic editor: A. Paton | Received 29 August 2020 | Accepted 31 October 2020 | Published 4 December 2020

Citation: Lorence DH, Wagner WL, Wood KR, Johnson G (2020) Pogostemon guamensis Lorence \& W.L.Wagner (Lamiaceae), a new species from Guam, Mariana Islands. PhytoKeys 169: 61-73. https://doi.org/10.3897/ phytokeys. 169.58107

\begin{abstract}
While undertaking a botanical survey of the Andersen Air Force Base on Guam (Mariana Islands) in 1994, botanists from the National Tropical Botanical Garden collected an unusual suffrutescent, nonaromatic member of the Lamiaceae family growing on limestone cliffs in the northeastern part of the island. Based on morphology and molecular data $(\operatorname{trn} L F$, mat $K)$, it was determined to belong to the genus Pogostemon Desf., a genus previously unknown from the Micronesian, Melanesian, and Polynesian region. Moreover, the analysis also showed that it was not conspecific with P. cablin (patchouli), and of the species available to include in the phylogenetic analyses it is sister to $P$. hirsutus s a species from India and Sri Lanka. Differing from its congeners by its large, loose inflorescence $2.5-5 \mathrm{~cm}$ wide and up to $7 \mathrm{~cm}$ wide in fruit, it is here illustrated and described as a new species, Pogostemon guamensis Lorence \& W.L. Wagner and its habitat and conservation status are discussed.
\end{abstract}

\section{Keywords}

conservation, Guam, Lamiaceae, Mariana Islands, Micronesia, Pogostemon

\section{Introduction}

Micronesia comprises the Caroline, Mariana, Gilbert, and Marshall Islands in the western Pacific Ocean and forms part of the Polynesia-Micronesia global biodiversity hotspot (Conservation International 2007). The Micronesian bioregion spans an area

Copyright David H. Lorence et al. This is an open access article distributed under the terms of the Creative Commons Attribution License (CC BY 4.0), which permits unrestricted use, distribution, and reproduction in any medium, provided the original author and source are credited. 
of the Pacific Ocean comparable in size to the continental United States or Australia, but the total land area of all the islands within this area is approximately $2,628 \mathrm{~km}^{2}$, smaller than the US state of Rhode Island. Recent studies suggest that Micronesia has the world's highest percentage of plant endemism per square kilometer out of all globally recognized insular biodiversity hotspots, with a total of 364 vascular plant species endemic to Micronesia (Costion and Lorence 2012). A new endemic species of Syzygium (Myrtaceae) was recently described from Palau, Caroline Islands (Byng et al. 2019), underscoring the need for further botanical exploration and study of the Micronesian flora.

The Mariana Islands are the northernmost of the island groups in Micronesia, and Guam is the southernmost island in the Mariana group with a land area of ca. $541 \mathrm{~km}^{2}$. The Marianas have 54 vascular plant endemics, with 11 single island endemics restricted to Guam, including two pteridophytes and nine angiosperms. The Lamiaceae are poorly represented in Micronesia, however, with only a single endemic species, Callicarpa lamii Hosok. restricted to the Marianas (Costion and Lorence 2012). A new species belonging to the genus Pogostemon was collected in Guam and is described herein. Along with the new Syzygium species from Palau, this brings the total number of known Micronesian endemic vascular plant species to 366.

Pogostemon Desf. (Lamiaceae: Lamioideae) is a genus of about 80 species of herbs or subshrubs with a center of diversity in tropical and subtropical Asia, with another five species endemic to Africa (Bhatti and Ingrouille 1997; Yao et al. 2015; Bongcheewin et al. 2017). Species diversity is highest in the Indian subcontinent. Diagnostic characters of the genus are exerted stamens bearded with moniliform hairs medially along the filaments, uni-thecal anthers, and a 2-lipped corolla with a 3-lobed upper lip and 1-lobed lower lip or subequally 4-lobed (Harley et al. 2004; Yao et al. 2015). The genus is named for its bearded staminal filaments (Latin/Greek pogos, beard, and stemon, stamen). Pogostemon cablin (Blanco) Benth. is well known and widely cultivated as the source of patchouli oil, an essential oil obtained from the leaves and used in soaps and perfumes. Dysophylla Blume, previously recognized as a distinct genus based on its small flowers and aquatic or marshland habitat, was reduced to a section of Pogostemon by Bhatti and Ingrouille (1997). Recent molecular phylogenetic studies suggest that Pogostemon s.l., including Dysophylla, is strongly supported to be monophyletic (Bendiksby et al. 2011).

An unusual species of Lamiaceae growing on the limestone cliffs of northeastern Guam (Mariana Islands) was first collected in 1982 by Derral Herbst and again in 1994 by Kenneth Wood and Steven Perlman of the National Tropical Botanical Garden during a botanical survey of the Andersen Air Force Base sponsored by the U.S. Fish and Wildlife Service (Perlman and Wood 1994). This is an area harboring rich native flora but with highly restricted access, and consequently its flora had not been well documented prior to this survey. Morphological and molecular studies have revealed it to be an undescribed species of Pogostemon apparently endemic to Guam which we describe and illustrate below. 


\section{Methods and materials}

This study is based on field observations in Guam and on herbarium collections from the Bernice P. Bishop Museum (BISH), the National Tropical Botanical Garden (PTBG), and the US National Herbarium (US). Besides the specimens cited below, no additional collections of this taxon were located in any other herbaria including the University of Guam Herbarium (GU) (Wei Xiao, pers. comm. 5 October 2020). Available gene sequences were downloaded from GenBank to ascertain whether it indeed belonged to the genus Pogostemon which it clearly does based on both morphological and molecular evidence. For the conservation assessment, we used the IUCN Red List categories and criteria (IUCN 2019).

\section{Molecular methods}

Total DNA was extracted from silica dried leaf material taken from 4 individuals collected in 1994, two collected by both S. Perlman and K. R. Wood. Fragments of leaf tissue approximating $1.0 \mathrm{~cm}^{2}$ were transferred $2.0 \mathrm{~mL}$ screw-capped, wide-base microcentrifuge tubes containing $-0.1 \mathrm{~mL} 1.0 \mathrm{~mm}$ diameter glass beads and ten $2.3 \mathrm{~mm}$ diameter silicazirconium beads (Biospec Products Inc., Bartlesville, OK, USA). Sample tubes were immersed in liquid nitrogen for 2 minutes and then tissues were homogenized into a fine powder using a MP FastPrep96 (MP BioMedicals LLC., Solon, OH, USA) at $1800 \mathrm{rpm}$ for 1 minute. To increase total yield from each sample, 6 separate tubes were prepared for each collection. To each tube, $500 \mu \mathrm{L}$ pre-warmed lysis buffer AP1 was added. After mixing, $10 \mu \mathrm{L}(50 \mathrm{mg} / \mathrm{mL})$ proteinase K (Bioline Inc., Taunton, MA, USA) and $10 \mu \mathrm{L}$ $\beta$-mercaptoethanol (Sigma-Aldrich, St. Louis, MO, USA) were added and the solutions incubated at $65^{\circ} \mathrm{C}$ for 1 hour and then reduced to $54^{\circ} \mathrm{C}$ overnight while agitating at $500 \mathrm{rpm}$ on a VorTemp rotary incubator (Labnet International, Inc., Edison, NJ, USA).

Each lysate was mixed with $150 \mu \mathrm{L}$ precipitation buffer $\mathrm{P} 3$ and incubated on ice for 5 minutes before centrifuging at $13,500 \mathrm{rpm}$ for 15 minutes at $4{ }^{\circ} \mathrm{C}$ to pelletize debris. The cleared supernatant was centrifuged at 13,500 rpm for 2 minutes through QiaShredder columns; all 6 lysates prepared for one sample were processed through the same column. Resulting eluates were pooled into a $15 \mathrm{~mL}$ conical vial and mixed with a $1.5 \times$ volume of binding buffer AW 1 and centrifuged in $600 \mu \mathrm{L}$ increments through a DNeasy column at $8,000 \mathrm{rpm}$ for 1 minute. The remainder of the extraction was conducted according to the manufacturer's protocol.

A portion of the maturase $K$ (matK) gene was amplified in two sections with the $1 \mathrm{Fa}$ and $3 \mathrm{R}$ primers for the 5 ' part and the $3 \mathrm{~F}$ and $5 \mathrm{Rb}$ for the 3 ' end as described by Bendiksby et al. (2011). The 5 ' end of the $\operatorname{trn} L^{(\mathrm{UUA})}$ intron was amplified using the $\mathrm{c}$ and d primers from Taberlet et al. (1991). The PCR amplifications and subsequent Sanger sequencing was conducted using the methods of Acevedo-Rodríguez et al. (2017).

The resulting chromatograms were edited and assembled into consensus sequences using Sequencher ver. 5.2.4 (Gene Codes, Ann Arbor, MI, USA). These sequences 
were compared with published matK and trnL intron sequences on GenBank (Scheen et al. 2010; Bendiksby et al. 2011; Chen et al. 2016; Yao et al. 2016; Yi and Kim 2016; Zhang et al. 2019). Alignments were created using MAFFT ver. 7 (Katoh and Standley 2013) and were analyzed with MrBayes 3.2.6 (Ronquist and Huelsenbeck 2003) to generate phylogenetic reconstructions with Bayesian Inference and the GTR + I + $\Gamma$ evolutionary model. Four Markov Chain Monte Carlo chains were run, each starting from a different random tree. One tree was sampled in every 1,000 of 2,000,000 generations when the standard deviation between split frequencies was less than 0.01 . After discarding the first $25 \%$ of trees as burn-in, the remaining trees were used to calculate posterior probabilities and a 50\% majority-rule consensus tree (Fig. 1).

\section{Molecular results}

DNAs obtained from Pogostemon guamensis collections by Wood and Perlman in 1994 were highly degraded. The use of the modified DNeasy extraction method described here with combining DNAs from six lysates for one DNeasy column increased the total yield. This enabled regions of trnL intron and matK to be PCR amplified and sequenced for half the extracts. Other common phylogenetic markers failed to amplify presumably due to the poor DNA quality. Collection information and GenBank accession numbers for the two samples that yielded sequenceable DNA are shown in Table 1.

The $m a t K$ region obtained for $P$. guamensis was diverged $0.6 \%$ from the closest related matKaccession on GenBank, P. hirsutus Benth. (HQ911397). In this pairwise comparison, 7 SNPs were identified over 1146 bp while trnL intron sequences were identical between $P$. guamensis and P. hirsutus (FJ854298). In contrast, at least 36 SNPs were identified between mat $K$ for $P$. guamensis and various accessions of the common horticultural herb patchouli, P. cablin (EF529553, EF529543, EF529554, and EF529546). Pairwise comparisons between 1,212 bp matK from patchouli and P. guamensis differed 3.1-3.6\% depending on the accession. With the more conserved $\operatorname{trnL}$ intron, they were $0.8 \%$ divergent.

The phylogenetic analyses were included for two specific purposes: 1) to determine if the species from Guam was indeed a member of Pogostemon; and 2) to determine whether it was a native part of the Guam flora or an introduction of $P$. cablin. In phylogenetic reconstructions of Pogostemon using matK sequences from GenBank, $P$. guamensis formed a strongly supported clade with $P$. hirsutus, $P$. mollis Benth., and $P$. wightii Benth. (Fig. 1). This group was nested within a larger well-supported clade containing other taxa from subgenera Allopogostemon (sensu Bhatti and Ingrouille 1997) and Dysophyllus section Verticillatus, Yao et al. (2016) placing subgen. Allopogostemon in synonymy of subgen. Dysophyllus. The clade containing P. guamensis was in a polytomy with a well-supported clade containing $P$. cablin with various species in subgen. Pogostemon and a clade of $P$. barbatus Bhatti \& Ingr. and P. auricularius (L.) Hassk. (Fig. 1). Although the resolving power was much lower, the topology of a Bayesian tree estimated with $\operatorname{trn} L$ intron data did not conflict with that generated from matK(data not shown). 


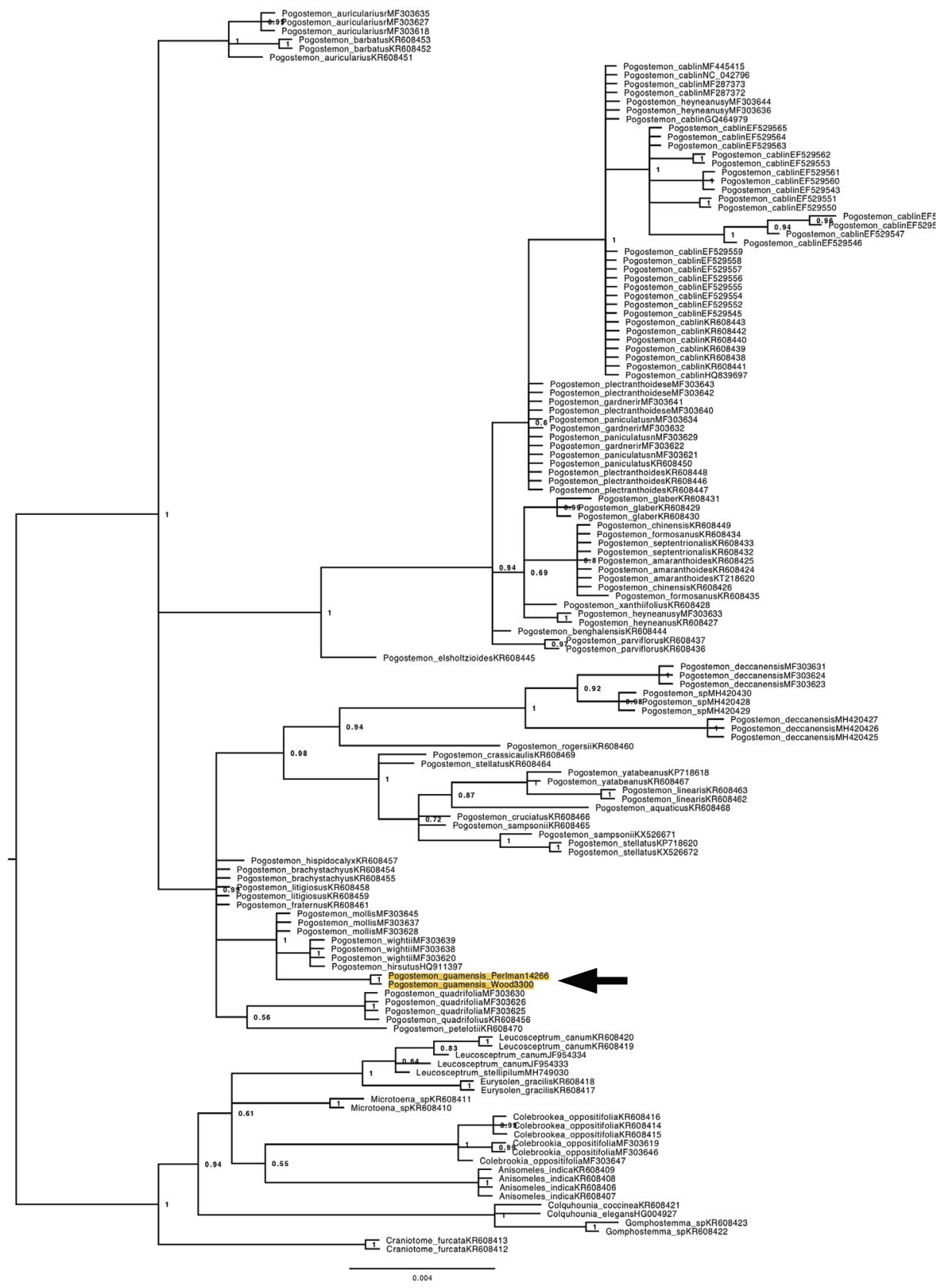

Figure I. A phylogenetic reconstruction of genus Pogostemon estimated using Baysean Inference of partial $m a t K$ sequences generated in this study and obtained from GenBank. Node labels indicate posterior probabilities. Based on matK evidence, a well-supported clade containing $P$. guamensis, P. hirsutus, $P$. wightii, and $P$. mollis is separate from that containing $P$. cablin, the common patchouli plant with a broad feral distribution and superficial resemblance to $P$. guamensis. Arrow and highlighting indicate samples of $P$. guamensis. 


\section{Molecular-Phylogenetic data (trnL, matK)}

Table I. Collection information and GenBank accession numbers for the two specimens used in the molecular analyses in this study.

\begin{tabular}{ccccccc}
\hline Name & Collector & Coll. No. & Coll. Date & Locality & matK & trnL $^{(\mathrm{UUA})}$ intron \\
\hline Pogostemon guamensis & Wood and Perlman & 3300 & $07 / 02 / 94$ & Guam, Pati Point & MT446026 & MT446028 \\
& Perlman and Wood & 14266 & $07 / 02 / 94$ & Guam, Pati Point & MT446025 & MT446027 \\
\hline
\end{tabular}

\section{Systematics}

\section{Pogostemon guamensis Lorence \& W.L.Wagner, sp. nov.} urn:lsid:ipni.org:names:77213186-1

Figures 2, 3

Type. Mariana Islands. Guam: Yigo Municipality. Andersen Air Force Base, Pati Point, just west of point, 10 degrees north aspect, 2 July 1994, S. P. Perlman \& K. R. Wood 14266 (Holotype PTBG 061045!; Isotypes BISH!, GU!, K!, NY!, UC!, US!).

Diagnosis. Shrub or subshrub growing on limestone cliffs, distinguishable from its congeners by its non-aromatic parts; inflorescence a loose thyrse, $2.5-5 \mathrm{~cm}$ wide and up to $7 \mathrm{~cm}$ wide in fruit; calyx equally 5(6)-toothed, externally densely hirtellous and internally glabrous; corolla white, weakly bilabiate, tube $8-10 \mathrm{~mm}$ long, externally sparsely white pilosulous in distal half, glabrous in basal half, internally pilosulous up to base of lobes; stamens long-exserted with filaments 13-14 mm long, bearded with septate, non-moniliform trichomes in basal half and glabrous in distal half or occasionally with trichomes along entire length, with anthers reniform, $0.4 \mathrm{~mm}$ long; style plus stigma ca. 15-16 mm long, stigma lobes 2, equal, linear, 1.6-2.2 mm long.

Description. Diffusely branching, non-aromatic perennial shrub or subshrub 75$130 \mathrm{~cm}$ tall, main stem to $2 \mathrm{~cm}$ diameter at base, bark pale brown, a pair of branches usually developing below each inflorescence, mature stems solid, weakly 4-angled, 3-3.2 mm wide, 4-sulcate, yellowish green when fresh, drying brown, stems, petioles, and inflorescences densely hirtellous with brown, patent, multicellular, non-glandular, 4-6-celled trichomes $0.1-0.2 \mathrm{~mm}$ long mixed with shorter capitate glandular trichomes $<0.1 \mathrm{~mm}$ long. Leaves opposite, when fresh somewhat fleshy, yellowish green adaxially, paler abaxially, drying brown, chartaceous, blade broadly ovate to ovate-cordate, (4.5)6-13.5 cm long, (3.5-)5-8.5 cm wide, adaxially uniformly hirtellous with antrorsely curved pale brown or whitish hairs $0.2-0.3 \mathrm{~mm}$ long, abaxially similarly hirtellous but with hairs denser on midrib, veins, and margin, surface densely yellowish-brown glandular punctate, margin serrate-crenate or biserrate-crenate, teeth obtuse, $0.4-1 \mathrm{~cm}$ apart, apex acute to short acuminate, the acumen to $1 \mathrm{~cm} \mathrm{long}$, base cordate to subcordate or sometimes truncate and rounded, secondary veins (4)5-6 on each side, basal pair arising near petiole insertion, tertiary venation reticulate, prominulous on both surfaces; petiole (2-)4-7 cm long, 1.2-1.5 mm wide, densely brown hirtellous. Inflorescence terminal, a single loose, densely flowered, cylindrical thyrse (3-)4.5-19 cm long, $2.5-5 \mathrm{~cm}$ wide, elongating to $20 \mathrm{~cm}$ long and $7 \mathrm{~cm}$ wide in fruit, when fresh 




Figure 2. Pogostemon guamensis Lorence and W.L.Wagner $\mathbf{A}$ habit, stem with leaves and inflorescence B detail of abaxial leaf surface showing pubescence and sessile glands $\mathbf{C}$ portion of inflorescence showing cymes with calyces and four corollas $\mathbf{D}$ calyx $\mathbf{E}$ corolla at anthesis $\mathbf{F}$ corolla, opened along one side $\mathbf{G}$ gynoecium with portion of calyx removed showing ovary and style. Drawn from Perlman and Wood 14295 (A, B), Wood and Perlman 3359 (C-E), and Wood and Perlman 3300 (F, G). Illustration by Alice Tangerini. 


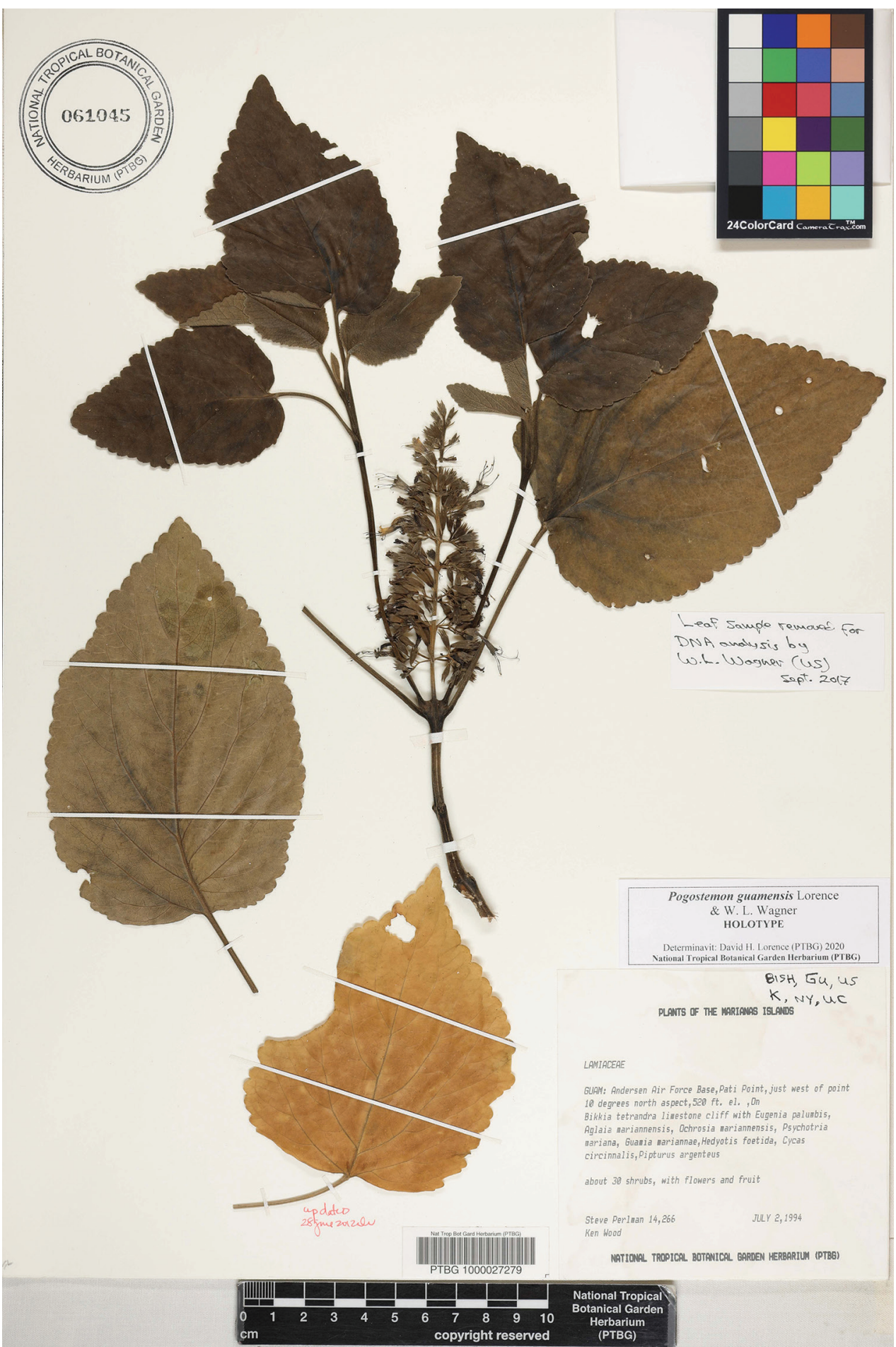

Figure 3. Pogostemon guamensis Lorence and W.L.Wagner (Perlman \& Wood 14266, holotype PTBG-061045). 
yellowish green, densely hirtellous, peduncle (4-) 10-15 mm long; flowers (25-) 50 to several hundred (rarely to ca. 700) per inflorescence; opposite cymes sessile or on peduncle $2-3 \mathrm{~mm}$ long, occasionally subtended by a narrowly triangular-subulate bract 3.5-6 mm long, cymes usually branched once, each branch (3-)6-20-flowered, rachis slightly undulating or zig-zag, elongating to $35 \mathrm{~mm}$ in fruit; flowers secund, on pedicel $0.5-2 \mathrm{~mm}$ long, subtended by (1-)2 narrowly subulate bracteoles $1-1.2 \mathrm{~mm}$ long; calyx radially symmetrical, equally 5(6)-toothed, externally densely hirtellous with patent or slightly ascending non-glandular trichomes, tube 4.5-6 mm long, obconic-cylindrical, 10(12)-veined, internally glabrous, teeth equal to slightly subequal, narrowly triangular-acute, $1.5-2.5 \mathrm{~mm}$ long, $0.8-1 \mathrm{~mm}$ wide at base, with distinct mid and marginal vein, densely hirtellous on both surfaces with scattered sessile glands; corolla white, venose when dry, exserted from calyx, funnelform, tube 8-10 mm long, slightly gibbous at base, $0.7-0.8 \mathrm{~mm}$ wide medially, $2-3 \mathrm{~mm}$ wide at apex of tube, 2-lipped, upper lip 3-lobed, lobes obtuse, ca. $1.3 \mathrm{~mm}$ long and wide, lower lip entire, $1.8-2 \mathrm{~mm}$ long, corolla tube externally sparsely white pilosulous in distal half, glabrous in basal half, internally pilosulous up to base of lobes; stamens 4, exserted 5-7 mm beyond corolla lobes, attached ca. 2-3 mm from base of tube, filaments $13-14 \mathrm{~mm}$ long, sparsely villous bearded in basal half with white septate (non-moniliform) trichomes and glabrous in distal half or occasionally with trichomes along entire length; anther reniform, $0.4 \mathrm{~mm}$ long; style terminal, glabrous, exserted, slightly longer than stamens, style plus stigma ca. 15-16 mm long, stigma lobes 2, equal, linear, 1.6-2.2 mm long. Nutlets 4, ellipsoid, smooth, c. $0.3 \mathrm{~mm}$ long, $0.2 \mathrm{~mm}$ wide (immature), mature nutlets not seen, said to be brown-black (Wood 3370, PTBG).

Distribution. Known only from the karstic limestone cliffs of northeastern Guam, Mariana Islands.

Phenology. Flowers were collected in April and July and immature fruit in July. In the many of the specimens examined flowers and nutlets had been eaten by herbivorous insects in the field, and consequently mature nutlets were not available for study.

Habitat and ecology. The northern end of Guam is characterized by a reef-associated limestone plateau that has been uplifted above sea level and flanked by cliffs that can exceed $190 \mathrm{~m}$ (c. $600 \mathrm{ft}$ ) high (Fig. 4). The forests growing on the elevated limestone plateau surrounding Andersen Air Force Base (AAFB) contain some of the richest native plant communities on Guam, although the forests and cliff habitat are often impacted by severe typhoons. The sharp, treacherously jagged karstic limestone makes it extremely dangerous for exploration and rappelling with ropes.

Pogostemon guamensis is known only from the dry to mesic karstic limestone cliffs of northeastern Guam at 370-550 ft (113-168 m) elevation, with small groupings occurring between Lafac Point to the south and the Tarague cliffs to the north. The coastal cliff community is dominated by halophytic scrub vegetation with woody species such as Aglaia mariannensis Merr., Bikkia tetrandra (L.f.) A. Rich., Eugenia bryanii Kaneh., E. palumbis Merr., E. reinwardtiana (Blume) DC., Excoecaria agollocha L., Ficus prolixa G. Forst., Guamia mariannae (Safford) Merr., Leptopetalum foetidum (G. Forst.) Neupane \& N. Wikstr., Macaranga thompsonii 


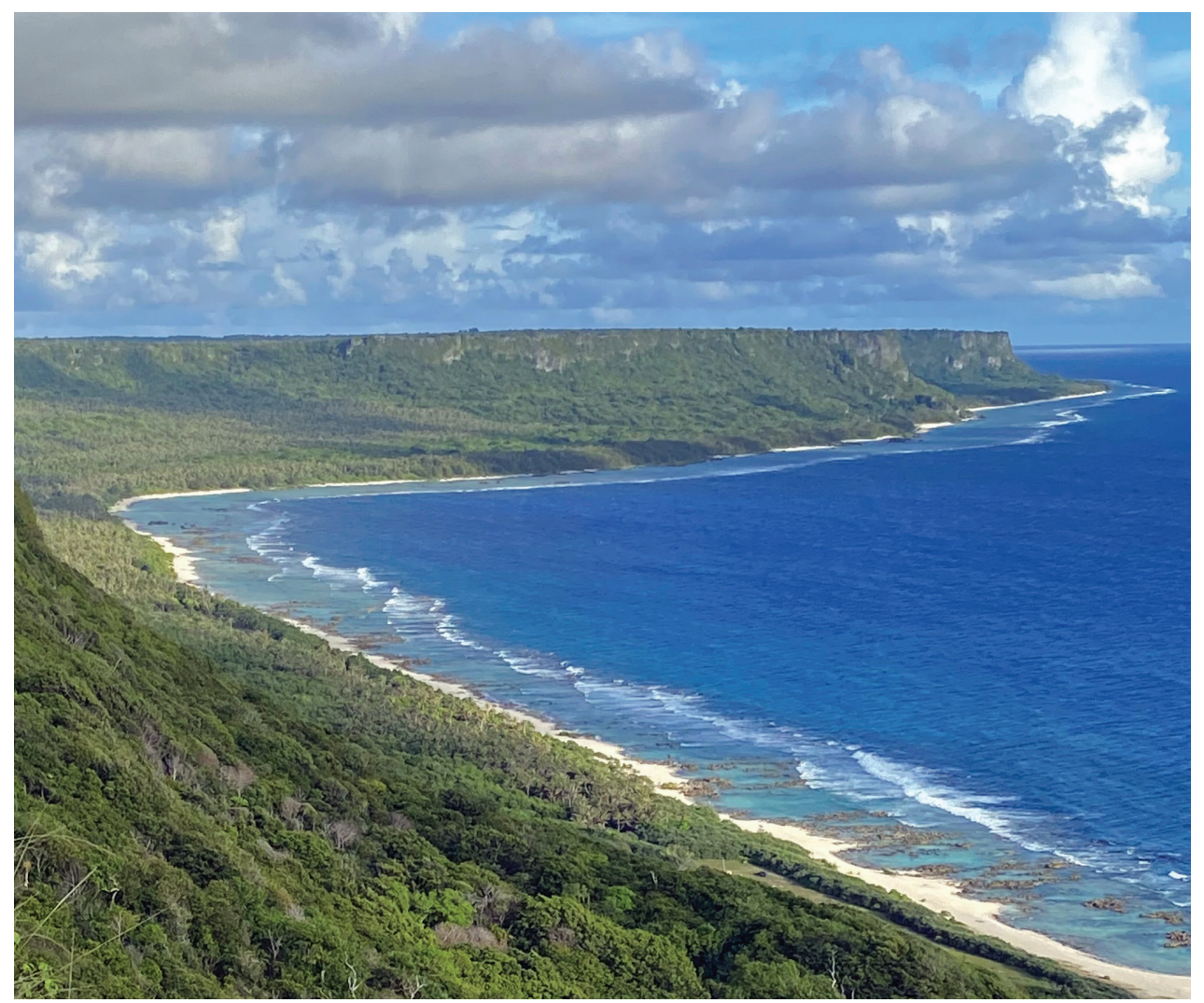

Figure 4. Coastal limestone cliffs of NE Guam, photo courtesy of Toni Mizerek.

Merr., Meiogyne cylindrocarpa (Burck) Heusden, Ochrosia mariannensis A. DC., Pemphis acidula J.R. Forst. \& G. Forst., Phyllanthus mariannensis W. L. Wagner \& Lorence, P. marianus Muell.-Arg, Pipturus argenteus (G. Forst.) Wedd., Polyscias grandifolia Volkens, Premna serratifolia L., Psychotria mariana Bartl. ex DC., Scaevola taccada (Gaertn.) Roxb., Syzygium thompsonii (Merr.) N. Snow, Triphasia trifolia (Burm.f.) P. Wilson, and Wikstroemia elliptica Merr., with associated herbaceous species including Cassytha filiformis L., and Peperomia mariannensis A. DC. Invasive alien plant species competing with the new species include Chromolaena odorata (L.) R.M. King \& H. Rob., Passiflora suberosa L., Sporobolus farinosus Hosok., and Triphasia trifolia (Burm.f.) P. Wils. Feral pigs (Sus scrofa) and the introduced Philippine or sambar deer (Rusa marianna) are also serious threats to the surrounding habitat, in addition to wind damage from severe typhoons.

Conservation status. During separate cliff rappels five subpopulations ranging in size from 1 to 30-50 plants were observed on vertical cliff faces, for a total of 113 individuals observed (Perlman and Wood 1994) (Fig. 5). Based on the IUCN categories and criteria this species is assigned a preliminary Red List status of Critically Endangered (CR) based on its $\mathrm{AOO}$ of $<10 \mathrm{~km}^{2}$ (i.e., $4 \mathrm{~km}^{2}$ ) and its $\mathrm{EOO}$ of $<100 \mathrm{~km}^{2}$ (i.e., 


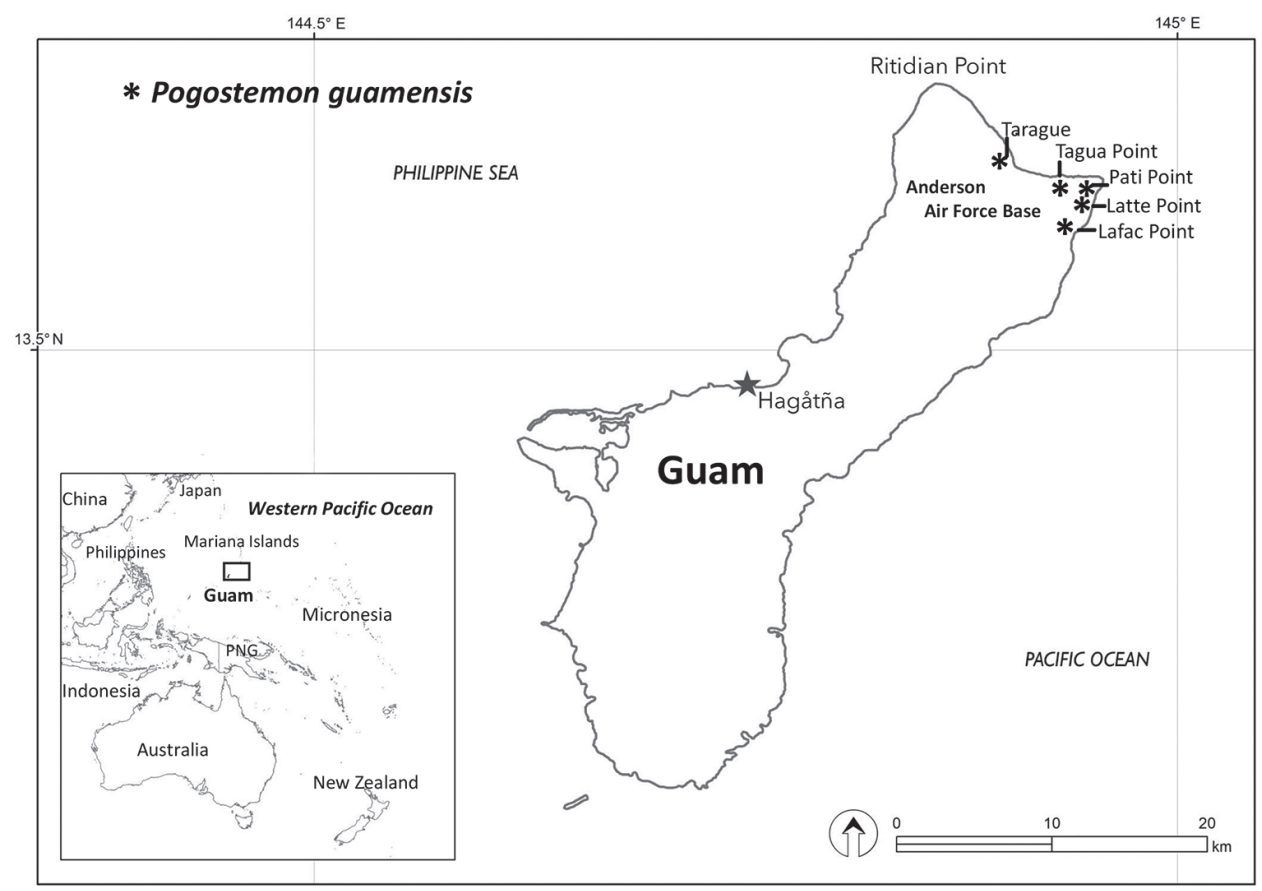

Figure 5. Distribution map showing five known localities for Pogostemon guamensis on NE part of Guam.

$4 \mathrm{~km}^{2}$ ), and it has only one known location, with continuing decline in both AOO and EOO inferred.

Specimens examined (Paratypes). Mariana Islands: Guam: Yigo MunicipalITy. Pati Point, ca. 500 ft., edge of limestone cliff, 14 April 1982, D. Herbst 6656 (BISH); Andersen Air Force Base, Pati Point area; 400-600 ft., N aspect. 2 July 1994, K. R. Wood 3300 (BISH, CAS, GU, MBK, NY, P, PTBG [2], US, WU); Andersen Air Force Base, near Tarague, steep cliffs around beach access road, 137 m, 18 Jul 1994, K. R. Wood 3370 (GU, PTBG, P, US); Andersen Air Force Base, Pati Pt., 350 degrees north aspect, rappel between 400-600 ft., 9 July 1994, K. R. Wood \& S. P. Perlman 3359 (GU, PTBG, US); Andersen Air Force Base, just north of Latte Point, between Latte and Pati Point, 5 July 1994, S. P. Perlman 14289 (GU, PTBG, MO, US); Andersen Air Force Base, west of Tagua, 400-550 ft., 330 deg. asp., 7 July 1994, K. $R$. Wood \& S. P. Perlman 3337 (GU, PTBG); Andersen Air Force Base, west of Tagua, between Tagua and Tarague, off Crow Transect 9, on cliff, 7 July 1994, S. P. Perlman \& K. R. Wood 14295 (GU, PTBG).

\section{Acknowledgments}

Field research in Guam was supported by the U.S. Fish and Wildlife Service (USFWS). The illustration was skillfully drawn by Alice Tangerini (Smithsonian Institution). For 
the molecular results all or portions of the laboratory and/or computer work were conducted in, and with the support of, the Laboratories of Analytical Biology facilities of the National Museum of Natural History or its partner labs. We thank Steven Perlman for useful discussions, information on habitat and ecology, and constructive comments on the manuscript, and also the anonymous reviewers whose comments improved the quality of the paper. Ben Nyberg assisted with preparation of the map, and Toni Mizerek contributed the photo of cliffs of NE Guam used in Fig. 3. We are grateful to Lauren Weisenberger for assistance with USFWS data. We thank the curators of the following herbaria for loans or permission to study their specimens: BISH, GU, PTBG, US. The contribution by WLW to this study was partially supported by the Smithsonian Research Opportunities Fund and while appointed as McBryde Chair at the National Tropical Botanical Garden.

\section{References}

Acevedo-Rodríguez P, Wurdack KJ, Ferrucci MS, Johnson G, Dias P, Coelho RG, Somner GV, Steinmann VW, Zimmer EA, Strong MT (2017) Generic relationships and classification of tribe Paullinieae (Sapindaceae) with a new concept of supertribe Paulliniodae. Systematic Botany 42: 96-114. https://doi.org/10.1600/036364417X694926

Bendiksby M, Thorbek L, Scheen AC, Lindquist C, Ryding O (2011) An updated phylogeny and classification of Lamiaceae subfamily Lamioideae. Taxon 60(2): 471-484. https://doi. org/10.1002/tax.602015

Bhatti GR, Ingrouille M (1997) Systematics of Pogostemon (Labiatae). Bulletin of the Natural History Museum. Botany Series 27(2): 77-147.

Bongcheewin B, Pramali K, Traiperm P, Chantaranothai P, Paton A (2017) Pogostemon nudus sp. nov. (Lamiaceae) from Thailand. Nordic Journal of Botany 35: 289-299. https://doi. org/10.1111/njb.01439

Byng J, Lorence DH, Xio W (2019) An annotated and illustrated checklist to Syzygium (Myrtaceae) 1: Micronesia. Phytotaxa 427(2): 115-130. https://doi.org/10.11646/phytotaxa.427.2.2

Chen ZD, Yang T, Lin L, Lu LM, Li HL, Sun M, Liu B, Chen M, Niu YT, Ye JF, Cao ZY (2016) Tree of life for the genera of Chinese vascular plants. Journal of Systematics and Evolution 54(4): 277-306. https://doi.org/10.1111/jse.12219

Conservation International (2007) Biodiversity Hotspots. Center for Applied Biodiversity Science. Published on the Internet. http://www.biodiversityhotspots.org/ [Accessed 23 July 2008]

Costion CM, Lorence DH (2012) The Endemic Plants of Micronesia: a Geographical Checklist and Commentary. Micronesica 43: 51-100. https://doi.org/10.3417/2011048

Harley RM, Atkins S, Budantsev AL, Cantino PD, Conn BJ, Grayer R, Harley MM, de Kok RPJ, Krestovskaja T, Morales R, Paton AJ, Ryding O, Upson T (2004) Labiatae. In: Kubitzki K (Ed.) The Families and Genera of Vascular Plants (Vol. VI). Springer-Verlag, Berlin, Heidelberg, New York, 167-275. https://doi.org/10.1007/978-3-642-18617-2_11 
Hutchinson DW, Strasburg JL, Shaffer C (2005) Cleaning microsatellite PCR products with Sephadex in 96-well filtration plates enhances genotyping quality. Biotechniques 38(1): 56-58. https://doi.org/10.2144/05381BM07

IUCN (2019) The IUCN Red List of Threatened Species. Categories \& Criteria. Version 20202). htpp://www.iucnredlist.org [Downloaded on 15 October 2020]

Katoh K, Standley DM (2013) MAFFT multiple sequence alignment software version 7: Improvements in performance and usability. Molecular Biology and Evolution 30: 772-780. https://doi.org/10.1093/molbev/mst010

Perlman S, Wood KR (1994) Anderson (sic) Air Force Base rare plant survey of their limestone Forests and cliffs, Northern Marianas Islands, Guam. Prepared for the U.S. Fish and Wildlife Service. National Tropical Botanical Garden, Botanical Survey Report (unpublished), 39 pp.

Ronquist F, Huelsenbeck JP (2003) MrBayes 3: Bayesian phylogenetic inference under mixed models. Bioinformatics 19: 1572-1574. https://doi.org/10.1093/bioinformatics/btg180

Scheen AC, Bendiksby M, Ryding O, Mathiesen C, Albert VA, Lindqvist C (2010) Molecular phylogenetics, character evolution, and suprageneric classification of Lamioideae (Lamiaceae) 1. Annals of the Missouri Botanical Garden 97(2): 191-217. https://doi. org/10.3417/2007174

Taberlet P, Gielly L, Pautou G, Bouvet J (1991) Universal primers for amplification of the three non-coding regions of chloroplast DNA. Plant Molecular Biology 17: 1105-1109. https:// doi.org/10.1007/BF00037152

Yao G, Deng Y-F, Ge X-J (2015) A taxonomic revision of Pogostemon (Lamiaceae) from China. Phytotaxa 200: 1-67. https://doi.org/10.11646/phytotaxa.200.1.1

Yao G, Drew BT, Yi TS, Yan HF, Yuan YM, Ge XJ (2016) Phylogenetic relationships, character evolution and biogeographic diversification of Pogostemon s.l. (Lamiaceae). Molecular Phylogenetics and Evolution 98: 184-200. https://doi.org/10.1016/j.ympev.2016.01.020

Yi DK, Kim K (2016) The complete chloroplast genome sequences of Pogostemon stellatus and Pogostemon yatabeanus (Lamiaceae). Mitochondrial DNA Part B 1(1): 571-573. https:// doi.org/10.1080/23802359.2016.1192509

Zhang C, Liu T, Yuan X, Huang H, Yao G, Mo X, Xue X, Yan H (2019) The plastid genome and its implications in barcoding specific-chemotypes of the medicinal herb Pogostemon cablin in China. PloS ONE 14(4): e0215512. https://doi.org/10.1371/journal.pone.0215512 